\title{
Post-production protein stability: trouble beyond the cell factory
}

Esther Vazquez ${ }^{1,2,3}$, José Luis Corchero ${ }^{3,1,2}$ and Antonio Villaverde ${ }^{1,2,3^{*}}$

\begin{abstract}
Being protein function a conformation-dependent issue, avoiding aggregation during production is a major challenge in biotechnological processes, what is often successfully addressed by convenient upstream, midstream or downstream approaches. Even when obtained in soluble forms, proteins tend to aggregate, especially if stored and manipulated at high concentrations, as is the case of protein drugs for human therapy. Post-production protein aggregation is then a major concern in the pharmaceutical industry, as protein stability, pharmacokinetics, bioavailability, immunogenicity and side effects are largely dependent on the extent of aggregates formation. Apart from acting at the formulation level, the recombinant nature of protein drugs allows intervening at upstream stages through protein engineering, to produce analogue protein versions with higher stability and enhanced therapeutic values.
\end{abstract}

Aggregation and associated conformational stress of cell factories (both prokaryotic and eukaryotic) are major concerns in recombinant protein production, resulting in low yields, unstable production and limited solubility and biological activity of the products [1-9]. Basic research on protein folding and the routine implementation of several analytical procedures such as circular dichroism, mass spectrometry and infrared spectroscopy (mostly incorporated from amyloid research) [4,10-16] have expanded our understanding of how polypeptide chains cross-interact and aggregate in vivo. In bacteria, probably the most studied cell factories, aggregation as inclusion bodies, a quite common event during production of heterologous polypeptides $[17,18]$, is now observed as a complex physiological event in which cellular agents, including chaperones $[6,19,20]$, proteases [21-23] and actin-like proteins [24] are coordinately acting $[24,25]$ in the frame of the cell's protein quality control machinery [26-28]. Despite aggregation as inclusion bodies might represent a source of relatively pure proteins for further refolding or extraction [29-33], or unexpectedly, a new type of nano-microparticulate biomaterials for biotechnological and biomedical applications [34-39], the use of recombinant proteins for most

\footnotetext{
* Correspondence: antoni.villaverde@uab.cat

${ }^{1}$ Institute for Biotechnology and Biomedicine, Universitat Autònoma de

Barcelona, Bellaterra, 08193 Barcelona, Spain

Full list of author information is available at the end of the article
}

of biotechnological and biomedical applications requires fully soluble protein versions. A particular issue in recombinant protein aggregation is the occurrence of soluble aggregates (less apparent that large aggregates), that are being progressively recognized in production processes. These soluble clusters adopt a spectrum of forms (mainly fibrilar, spherical or amorphous) [40,41] and might be the in vivo physiological precursors and structural components of bacterial inclusion bodies $[24,42]$. Very different approaches have been explored at upstream, midstream and downstream levels to minimize aggregation during recombinant protein production (Figure 1). Such strategies, eventhough being mostly a trial-and-error process, often result in significant improvements of protein solubility [43-46].

Desirably, soluble versions of recombinant proteins should keep such soluble status in post-production stages, that is, during storage and use. This need is specially acute in the case of proteins intended for therapeutic uses $[47,48]$. Protein drugs are commonly administered parenterally [49], what makes protein aggregation in stocks or upon administration a main concern in the Pharma industry (see for instance, http:// www.eahp.eu/content/download/25193/164355/.../CoverStory20-21.pdf.pd). The high concentration at which proteins drugs are stored and administered [50] specifically favors aggregation [51]. In this context, diverse analytical procedures have been developed and 


\section{Production}

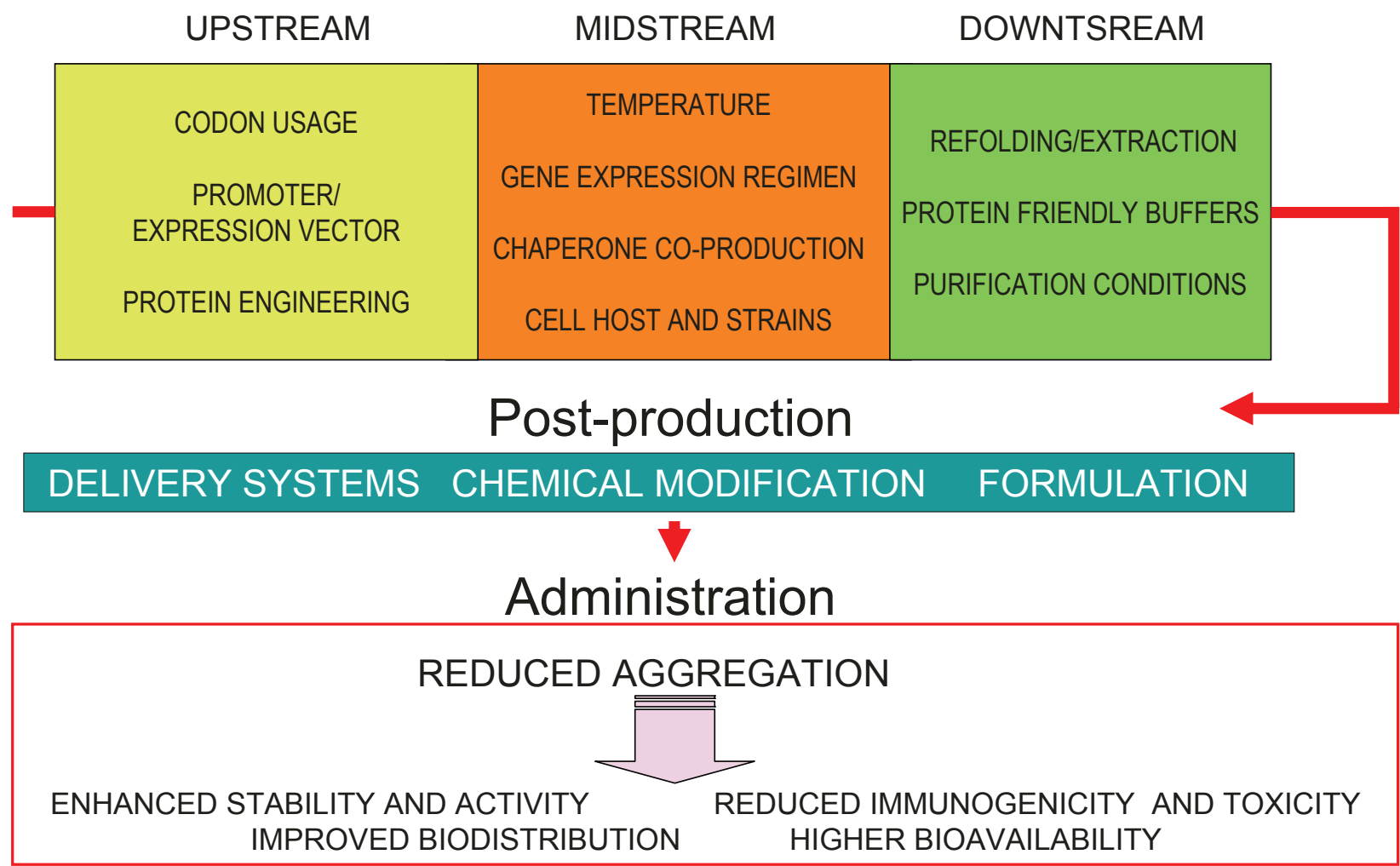

\section{ADDED CLINICAL VALUES}

\section{CELL/TISSUE TARGETING CELL PENETRATION BBB CROSSING MULTIFUNCTION}

Figure 1 Tool boxes through which protein solubility can be enhanced at different stages of protein production and postproduction pipelines. Targets for improvement during in vivo administration are summarized in the red framed box, some of them being modulated by protein aggregation. Appropriate codon selection [82,83], using weak promoters or low copy number plasmids and protein engineering [84] are the most common upstream strategies (yellow box). Growth at sub-optimal temperatures [85,86], mild induction of gene expression, coproduction of chaperones [87-89] or protein production in protease-deficient strains [90,91] or in mutants with altered redox properties [92] favor correct protein folding (orange box). Buffers and purification conditions should be optimized as per protein basis to prevent aggregation [93-97]. Alternatively, soluble protein species can be obtained by refolding inclusion body proteins [30-32] or by extracting functional proteins from inclusion bodies by mild procedures [29] (green box). Once purified, aggregation during storage or administration of protein drugs can be inhibited by appropriate excipient formulations or by chemical modification $[50,60,62,98]$ (blue box). Also, the use of delivery systems, either through protein adsorption onto nanoparticles, nano and micro encapsulation or embedding in biocompatible materials stabilize proteins, expand their half-life in the body and permit a sustained release, resulting in enhanced bioavailability and reduced toxicity [63,64,99]. Upstream protein engineering strategies that enhance solubility during production can also affect aggregation and performance of protein drugs upon administration. Also, by this approach, novel functions that improve pharmacological performance of proteins can be gained without necessarily enhancing solubility (bottom, green framed box).

specifically adapted to the detection of therapeutic protein aggregation [52-54]. Importantly, aggregation does not only render drug inactivation during storage, and fast clearance, reduction of activity, limited bioavailability and proteolytic digestion upon administration, but it also stimulates undesired immunogenicity [55]. This is a critical issue in clinics as severe side effects observed upon prolonged protein administration (as in the case of insulins, interferons, erythropoietin and growth hormone) are antibody-dependent [56-59].

Chemical modification of proteins and the use of appropriate excipients (Figure 1) are the most taken approaches for protein drug stabilization [60-62]. Obviously, emerging concepts in Nanotechnology, Nanomedicine and in Material Sciences offer new biocompatible vehicles for protein encapsulation or 
embedding, mainly at the nanoscale, through which the stability, tissue targeting and bioavailability during drug delivery are dramatically enhanced $[63,64]$. Many among those such nanostructured materials are from bacterial origin [65].

Being proteins flexible molecules suitable to be redesigned by genetic methods, upstream protein engineering, one of the main approaches to prevent aggregation during production (Table 1, up), is also useful to stabilize protein drugs during use (Table 1, bottom). In addition, modification of the protein primary sequence permits a fine tuning of protein features such as oligomerization, activity, cell targeting and cell penetration, that represent additional values in the performance of a protein drug (Table 1; Figure 1, bottom). In this regard, protein engineering is revealed as an extremely flexible approach to enhance the stability of proteins during production, storage and use, but also to improve their performance in in vivo uses. Reduction of aggregation is expected to minimize immunogenicity, increase proteolytic stability, improve bioavailability and limit sideeffects, as aggregation has a pivotal role in all these issues [55,59,66-69]. In addition, protein modification can offer added values to protein drugs, by conferring novel functions that improve pharmacological performance without necessarily enhancing solubility (Figure 1 , green framed box). These include cell or tissue targeting or enhanced cell penetration by the fusion to a cell receptor ligand or an antibody [70-74], enhancing halflife and bioavailability by fusion to transferrin [75], albumin [76], or albumin-binding peptides [77] and crossing the brain-blood barrier (BBB) by the incorporation of cationic peptides [78]. Creating multifunctional proteins by the appropriate combination of protein domains in a single polypeptide chain is being especially explored for the construction of protein-only artificial viruses, in

Table 1 Protein engineering strategies to reduce aggregation or derived effects during either production or administration, illustrated by representative examples.

\begin{tabular}{|c|c|c|c|}
\hline Protein engineering strategy & Result & Protein & Reference \\
\hline \multicolumn{4}{|l|}{ Improving protein folding during production } \\
\hline Cys $\rightarrow$ Ser point mutations & $\begin{array}{l}\text { Reduced aggregation, enhanced proteolytic } \\
\text { stability }\end{array}$ & $\mathrm{bFGF}^{\mathrm{a}}$ & {$[100]$} \\
\hline Point mutations in an hydrophobic stretch & Reduced aggregation & 11 beta-HSD1 & [101] \\
\hline Directed evolution/point mutations & Reduced aggregation & Cytochrome P450sca-2 & {$[102]$} \\
\hline Fusion of SUMO tag & Improved refolding & Fgf15 & [103] \\
\hline Polycationic amino acid tag fusion & Reduced aggregation & $\begin{array}{l}\text { Candida antarctica } \\
\text { lipase B }\end{array}$ & [104] \\
\hline Fusion to polylysines or polyarginines & Reduced aggregation & BPTI-22 & {$[105]$} \\
\hline Fusion to MBP & Reduced aggregation & Ribonuclease inhibitor & {$[106]$} \\
\hline Fusion to GrpE & Reduced aggregation & hIL-3 & [107] \\
\hline Fusion to NusA & $\begin{array}{l}\text { Reduced aggregation, enhanced proteolytic } \\
\text { stability }\end{array}$ & E8R viral protein & [108] \\
\hline \multicolumn{4}{|l|}{$\begin{array}{l}\text { Improving protein folding, stability and performance } \\
\text { during administration }\end{array}$} \\
\hline Single amino acid substitution & $\begin{array}{l}\text { Inhibited oligomer formation; enhanced } \\
\text { bioavailability }\end{array}$ & Insulin Aspart ${ }^{\circledR}$ & [109] \\
\hline Single amino acid substitution & Improved folding & INF- $\beta$-1b (Betaferon ${ }^{\circledR}$ ) & [110] \\
\hline N-terminal peptide deletion & Enhanced stability & KGF & [111] \\
\hline Fusion with albumin & Extended half-life & Albinterferon $\alpha-2 b$ & [76] \\
\hline Fusion with transferrin & Enhanced gastrointestinal adsorption & hGH & [75] \\
\hline Artificial consensus protein sequence & Enhanced activity & $\begin{array}{l}\text { Interferon } \alpha \text { con-1 } \\
\text { (Infergen }{ }^{\mathbb{B}} \text { ) }\end{array}$ & {$[112]$} \\
\hline Fusion of a HIV Tat segment & Enhanced solubility & p53 & [113] \\
\hline Fusion of a HIV Tat protein and ODD & $\begin{array}{l}\text { Enhanced stability and activity in hypoxic } \\
\text { tumor cells }\end{array}$ & Casp-3 & [114] \\
\hline Fusion of a HIV Tat protein and sequence modification & $\begin{array}{l}\text { Cell penetration and selective activation in HIV- } \\
\text { infected cells }\end{array}$ & Casp-3 & [115] \\
\hline Ligand incorporation (mainly antibody fragments) & Enhanced stability and bioavailbility & $\mathrm{IL}-2$ & {$[71]$} \\
\hline
\end{tabular}

a Abbreviations are: 11 beta-HSD1, 11 beta-Hydroxysteroid dehydrogenase type 1; aFGF, acidic fibroblast growth factor; bFGF: Fgf15, Fibroblast growth factor 15; BPTI-22, Bovine pancreatic trypsin inhibitor variant 22; Casp-3, caspase 3; HIV, human immunodeficiency virus; hFGF, Human basic fibroblast growth factor; BSA bovine serum albumin; HAS, human serum albumin; hGH, human growth hormone; hIL-3, human interleukin-3; KGF, keratinocyte growth factor; IL, interleukin; $\mathrm{MAGOH}$, Protein mago nashi homolog; MBP, maltose-binding protein; OOD, oxygen-dependent degradation domain of hypoxia-inducible factor-1alpha; rhDNase, recombinant human DNAse; SUMO, small ubiquitin-related modifier. 
which the therapeutic nucleic acids are encapsulated by chimerical protein building blocks [72,79-81]. Further exploration of protein engineering focused on post-production issues is strongly required and it should allow the emergence of optimized drugs to fulfill their increasing demand.

\section{Conclusions}

Stability and solubility of recombinant proteins is a critical issue at both production and post-production stages. For a biomedical use of proteins as pharmaceuticals, high solubility not only supports stability but it also enhances bioavailability and reduces immunogenicity and undesired toxic effects. Among other approaches to stabilize protein drugs, such as chemical modification, proper formulation and encapsulation, protein engineering is a very flexible route to improve protein folding during production and reduce aggregation during storage and in vivo. Furthermore, the modification of protein primary sequence permits to confer additional functional values, such as binding to serum albumin, binding to cell surface receptors and cell membrane (or $\mathrm{BBB}$ ) crossing, thus improving biodistribution, expanding the half-life and enhancing the biological potential of the drug. The wide spectrum of possibilities of postproduction-addressed protein engineering is probably to be yet realized.

\section{Acknowledgements}

We appreciate the financial support received for the design and microbial production of recombinant proteins for biomedical applications from FISS (PS09/00165), MICINN (BFU2010-17450, ACI2009-0919, IT2009-0021, EUI200803610), AGAUR (2009SGR-108), CIBER de Bioingeniería, Biomateriales y Nanomedicina (CIBER-BBN), Spain, and from the European Science Foundation, which is also funded by the European Commission, Contract no. ERAS-CT-2003-980409 of the Sixth Framework Programme (ERANET-IB 08007). The authors also appreciate the financial support through the project "Development of nanomedicines for enzymatic replacement therapy in Fabry disease" granted by the Fundació Marató TV3.

\section{Author details \\ ${ }^{1}$ Institute for Biotechnology and Biomedicine, Universitat Autònoma de Barcelona, Bellaterra, 08193 Barcelona, Spain. ${ }^{2}$ Department of Genetics and Microbiology, Universitat Autònoma de Barcelona, Bellaterra, 08193 Barcelona, Spain. ${ }^{3} \mathrm{CIBER}$ de Bioingeniería, Biomateriales y Nanomedicina (CIBER-BBN), Bellaterra, 08193 Barcelona, Spain.}

\section{Competing interests}

The authors declare that they have no competing interests.

Received: 25 July 2011 Accepted: 1 August 2011

Published: 1 August 2011

\section{References}

1. Gasser B, Saloheimo M, Rinas U, Dragosits M, Rodriguez-Carmona E, Baumann $\mathrm{K}$, et al: Protein folding and conformational stress in microbial cells producing recombinant proteins: a host comparative overview. Microb Cell Fact 2008, 7:11.

2. Ciplys E, Samuel D, Juozapaitis M, Sasnauskas K, Slibinskas R: Overexpression of human virus surface glycoprotein precursors induces cytosolic unfolded protein response in Saccharomyces cerevisiae. Microb Cell Fact 2011, 10:37

3. Parrilli E, Giuliani M, Marino G, Tutino ML: Influence of production process design on inclusion bodies protein: the case of an Antarctic flavohemoglobin. Microb Cell Fact 2010, 9:19.

4. Ami D, Natalello A, Schultz T, Gatti-Lafranconi P, Lotti M, Doglia SM, et al: Effects of recombinant protein misfolding and aggregation on bacterial membranes. Biochim Biophys Acta 2009, 1794:263-269.

5. Guillemette T, van Peij NN, Goosen T, Lanthaler K, Robson GD, Van Den Hondel CA, et al: Genomic analysis of the secretion stress response in the enzyme-producing cell factory Aspergillus niger. BMC Genomics 2007, 8:158.

6. Martinez-Alonso M, Garcia-Fruitos E, Ferrer-Miralles N, Rinas U, Villaverde A: Side effects of chaperone gene co-expression in recombinant protein production. Microb Cell Fact 2010, 9:64.

7. Martinez-Alonso M, Gonzalez-Montalban N, Garcia-Fruitos E, Villaverde A Learning about protein solubility from bacterial inclusion bodies. Microb Cell Fact 2009, 8:4.

8. Dragosits M, Frascotti G, Bernard-Granger L, Vazquez F, Giuliani M, Baumann $K$, et al: Influence of growth temperature on the production of antibody Fab fragments in different microbes: a host comparative analysis. Biotechnol Prog 2011, 27:38-46.

9. Mattanovich D, Gasser B, Hohenblum H, Sauer M: Stress in recombinant protein producing yeasts. J Biotechnol 2004, 113:121-135.

10. Carrio M, Gonzalez-Montalban N, Vera A, Villaverde A, Ventura S: Amyloidlike properties of bacterial inclusion bodies. J Mol Biol 2005, 347:1025-1037.

11. Oberg K, Chrunyk BA, Wetzel R, Fink AL: Nativelike secondary structure in interleukin-1 beta inclusion bodies by attenuated total reflectance FTIR. Biochemistry 1994, 33:2628-2634.

12. Doglia SM, Ami D, Natalello A, Gatti-Lafranconi P, Lotti M: Fourier transform infrared spectroscopy analysis of the conformational quality of recombinant proteins within inclusion bodies. Biotechnol J 2008, 3:193-201

13. Gonzalez-Montalban N, Natalello A, Garcia-Fruitos E, Villaverde A, Doglia SM: In situ protein folding and activation in bacterial inclusion bodies. Biotechnol Bioeng 2008, 100:797-802.

14. Ami D, Natalello A, Taylor G, Tonon G, Maria DS: Structural analysis of protein inclusion bodies by Fourier transform infrared microspectroscopy. Biochim Biophys Acta 2006, 1764:793-799.

15. Ami D, Natalello A, Gatti-Lafranconi P, Lotti M, Doglia SM: Kinetics of inclusion body formation studied in intact cells by FT-IR spectroscopy. FEBS Lett 2005, 579:3433-3436.

16. Ami D, Bonecchi L, Cali S, Orsini G, Tonon G, Doglia SM: FT-IR study of heterologous protein expression in recombinant Escherichia coli strains. Biochim Biophys Acta 2003, 1624:6-10.

17. Villaverde $A$, Carrio MM: Protein aggregation in recombinant bacteria: biological role of inclusion bodies. Biotechnol Lett 2003, 25:1385-1395.

18. Baneyx F, Mujacic M: Recombinant protein folding and misfolding in Escherichia coli. Nat Biotechnol 2004, 22:1399-1408.

19. Gonzalez-Montalban N, Carrio MM, Cuatrecasas S, Aris A, Villaverde A: Bacterial inclusion bodies are cytotoxic in vivo in absence of functional chaperones DnaK or GroEL. J Biotechnol 2005, 118(4):406-412.

20. Carrio MM, Villaverde A: Localization of chaperones DnaK and GroEL in bacterial inclusion bodies. J Bacteriol 2005, 187:3599-3601.

21. Jurgen B, Breitenstein A, Urlacher V, Buttner K, Lin H, Hecker M, et al: Quality control of inclusion bodies in Escherichia coli. Microb Cell Fact 2010, 9:41.

22. Vera A, Aris A, Carrio M, Gonzalez-Montalban N, Villaverde A: Lon and ClpP proteases participate in the physiological disintegration of bacterial inclusion bodies. J Biotechnol 2005, 119:163-171.

23. Carbonell $X$, Villaverde A: Protein aggregated into bacterial inclusion bodies does not result in protection from proteolytic digestion. Biotechnology Letters 2002, 24:1939-1944.

24. Rokney A, Shagan M, Kessel M, Smith Y, Rosenshine I, Oppenheim AB: E. coli transports aggregated proteins to the poles by a specific and energy-dependent process. J Mol Biol 2009, 392:589-601.

25. Garcia-Fruitos E, Martinez-Alonso M, Gonzalez-Montalban N, Valli M, Mattanovich D, Villaverde A: Divergent Genetic Control of Protein Solubility and Conformational Quality in Escherichia coli. J Mol Biol 2007, 374:195-205 
26. Ventura S, Villaverde A: Protein quality in bacterial inclusion bodies. Trends Biotechnol 2006, 24:179-185.

27. Tyedmers J, Mogk A, Bukau B: Cellular strategies for controlling protein aggregation. Nat Rev Mol Cell Biol 2010, 11(11):777-788.

28. Gonzalez-Montalban N, Garcia-Fruitos E, Villaverde A: Recombinant protein solubility-does more mean better? Nat Biotechnol 2007, 25:718-720.

29. Peternel S, Grdadolnik J, Gaberc-Porekar V, Komel R: Engineering inclusion bodies for non denaturing extraction of functional proteins. Microb Cell Fact 2008, 7:34.

30. Jungbauer A, Kaar W: Current status of technical protein refolding. J Biotechnol 2007, 128:587-596.

31. Singh SM, Panda AK: Solubilization and refolding of bacterial inclusion body proteins. J Biosci Bioeng 2005, 99:303-310.

32. Vallejo LF, Rinas $\mathrm{U}$ : Strategies for the recovery of active proteins through refolding of bacterial inclusion body proteins. Microb Cell Fact 2004, 3:11

33. Cabrita LD, Bottomley SP: Protein expression and refolding - A practical guide to getting the most out of inclusion bodies. Biotechnol Annu Rev 2004, 10:31-50

34. Garcia-Fruitos E, Villaverde A: Friendly production of bacterial inclusion bodies. Korean J Chem Eng 2010, 27:385-389.

35. Vazquez E, Villaverde A: Engineering building blocks for self-assembling protein nanoparticles. Microb Cell Fact 2010, 9:101.

36. Villaverde A: Nanotechnology, bionanotechnology and microbial cell factories. Microb Cell Fact 2010, 9:53.

37. Rodriguez-Carmona E, Cano-Garrido O, Seras-Franzoso J, Villaverde A, Garcia-Fruitos E: Isolation of cell-free bacterial inclusion bodies. Microb Cell Fact 2010, 9:71.

38. Peternel $S$, Komel R: Isolation of biologically active nanomaterial (inclusion bodies) from bacterial cells. Microb Cell Fact 2010, 9:66.

39. Garcia-Fruitos E: Inclusion bodies: a new concept. Microb Cell Fact 2010, 9:80.

40. de Marco A, Sevastsyanovich YR, Cole JA: Minimal information for protein functional evaluation (MIPFE) workshop. N Biotechnol 2009, 25:170

41. de Marco A: Minimal information: an urgent need to assess the functional reliability of recombinant proteins used in biological experiments. Microb Cell Fact 2008, 7:20.

42. Morell M, Bravo R, Espargaro A, Sisquella X, Aviles FX, FernandezBusquets $X$, et al: Inclusion bodies: specificity in their aggregation process and amyloid-like structure. Biochim Biophys Acta 2008 1783:1815-1825

43. Sorensen HP, Mortensen KK: Soluble expression of recombinant proteins in the cytoplasm of Escherichia coli. Microb Cell Fact 2005, 4:1.

44. Makino T, Skretas G, Georgiou G: Strain engineering for improved expression of recombinant proteins in bacteria. Microb Cell Fact 2011, 10:32

45. Kolaj O, Spada S, Robin S, Wall JG: Use of folding modulators to improve heterologous protein production in Escherichia coli. Microb Cell Fact 2009, 8:9.

46. Sorensen HP, Mortensen KK: Advanced genetic strategies for recombinant protein expression in Escherichia coli. J Biotechnol 2005, 115:113-128.

47. Ferrer-Miralles N, Domingo-Espin J, Corchero JL, Vazquez E, Villaverde A: Microbial factories for recombinant pharmaceuticals. Microb Cell Fact 2009, 8:17

48. Leader B, Baca QJ, Golan DE: Protein therapeutics: a summary and pharmacological classification. Nat Rev Drug Discov 2008, 7:21-39.

49. Antosova Z, Mackova M, Kral V, Macek T: Therapeutic application of peptides and proteins: parenteral forever? Trends Biotechnol 2009, 27:628-635.

50. Shire SJ, Shahrokh Z, Liu J: Challenges in the development of high protein concentration formulations. J Pharm Sci 2004, 93:1390-1402.

51. Ellis RJ, Minton AP: Protein aggregation in crowded environments. Bio Chem 2006, 387:485-497.

52. Garcia-Fruitos E, Vazquez E, Gonzalez-Montalban N, Ferrer-Miralles N, Villaverde A: Analytical Approaches for Assessing Aggregation of Protein Biopharmaceuticals. Curr Pharm Biotechnol 2011.

53. Bobst CE, Kaltashov IA: Advanced Mass Spectrometry-Based Methods for the Analysis of Conformational Integrity of Biopharmaceutical Products. Curr Pharm Biotechnol 2011.

54. Bertucci C, Pistolozzi M, De SA: Structural Characterization of Recombinant Therapeutic Proteins by Circular Dichroism. Curr Pharm Biotechnol 2011
55. Richard J, Prang N: The formulation and immunogenicity of therapeutic proteins: Product quality as a key factor. IDrugs 2010, 13:550-558.

56. Katagiri D, Shibata M, Katsuki T, Masumoto S, Katsuma A, Minami E, et al: Antiepoetin antibody-related pure red cell aplasia: successful remission with cessation of recombinant erythropoietin alone. Clin Exp Nephrol 2010, 14:501-505

57. Braun A, Kwee L, Labow MA, Alsenz J: Protein aggregates seem to play a key role among the parameters influencing the antigenicity of interferon alpha (IFN-alpha) in normal and transgenic mice. Pharm Res 1997, 14:1472-1478.

58. Frost $\mathrm{H}$ : Antibody-mediated side effects of recombinant proteins. Toxicology 2005, 209:155-160

59. Fradkin AH, Carpenter JF, Randolph TW: Immunogenicity of aggregates of recombinant human growth hormone in mouse models. J Pharm Sci 2009, 98:3247-3264.

60. Jorgensen L, Hostrup S, Moeller EH, Grohganz H: Recent trends in stabilising peptides and proteins in pharmaceutical formulation considerations in the choice of excipients. Expert Opin Drug Deliv 2009, 6:1219-1230

61. Arakawa T, Tsumoto K, Kita Y, Chang B, Ejima D: Biotechnology applications of amino acids in protein purification and formulations. Amino Acids 2007, 33:587-605.

62. Frokjaer S, Otzen DE: Protein drug stability: a formulation challenge. Nat Rev Drug Discov 2005, 4:298-306.

63. Parveen S, Misra R, Sahoo SK: Nanoparticles: a boon to drug delivery, therapeutics, diagnostics and imaging. Nanomedicine 2011.

64. Singh S: Nanomedicine-nanoscale drugs and delivery systems. J Nanosc Nanotechnol 2010, 10:7906-7918.

65. Rodriguez-Carmona E, Villaverde A: Nanostructured bacterial materials for innovative medicines. Trends Microbiol 2010, 18:423-430.

66. Antonelli G: Reflections on the immunogenicity of therapeutic proteins. Clin Microbiol Infect 2008, 14:731-733.

67. De Groot AS, Scott DW: Immunogenicity of protein therapeutics. Trends Immunol 2007, 28:482-490.

68. Hermeling S, Schellekens H, Maas C, Gebbink MF, Crommelin DJ, Jiskoot W: Antibody response to aggregated human interferon alpha2b in wildtype and transgenic immune tolerant mice depends on type and level of aggregation. J Pharm Sci 2006, 95:1084-1096.

69. Schellekens $\mathrm{H}$ : Bioequivalence and the immunogenicity of biopharmaceuticals. Nat Rev Drug Discov 2002, 1:457-462.

70. Pardridge WM: Blood-brain barrier delivery of protein and non-viral gene therapeutics with molecular Trojan horses. J Control Release 2007, 122(3):345-348.

71. Sondel PM, Hank JA, Gan J, Neal Z, Albertini MR: Preclinical and clinical development of immunocytokines. Curr Opin Investig Drugs 2003, 4:696-700

72. Vazquez E, Ferrer-Miralles N, Mangues R, Corchero JL, Schwartz S Jr, Villaverde A: Modular protein engineering in emerging cancer therapies. Curr Pharm Des 2009, 15:893-916.

73. Boado RJ, Zhang Y, Zhang Y, Pardridge WM: Genetic engineering, expression, and activity of a fusion protein of a human neurotrophin and a molecular Trojan horse for delivery across the human blood-brain barrier. Biotechnol Bioeng 2007, 97:1376-1386.

74. Dietz GP, Bahr M: Delivery of bioactive molecules into the cell: the Trojan horse approach. Mol Cell Neurosci 2004, 27:85-131.

75. Amet N, Wang W, Shen WC: Human growth hormone-transferrin fusion protein for oral delivery in hypophysectomized rats. J Control Release 2010, 141:177-182

76. Subramanian GM, Fiscella M, Lamouse-Smith A, Zeuzem S, McHutchison JG: Albinterferon alpha-2b: a genetic fusion protein for the treatment of chronic hepatitis C. Nat Biotechnol 2007, 25:1411-1419.

77. Dennis MS, Zhang M, Meng YG, Kadkhodayan M, Kirchhofer D, Combs D, et al: Albumin binding as a general strategy for improving the pharmacokinetics of proteins. J Biol Chem 2002, 277:35035-35043.

78. de Boer AG, Gaillard PJ: Drug targeting to the brain. Annu Rev Pharmacol Toxicol 2007, 47:323-355.

79. Aris A, Villaverde A: Modular protein engineering for non-viral gene therapy. Trends Biotechnol 2004, 22:371-377.

80. Vazquez E, Ferrer-Miralles N, Villaverde A: Peptide-assisted traffic engineering for nonviral gene therapy. Drug Discov Today 2008, 13:1067-1074. 
81. Ferrer-Miralles N, Vazquez E, Villaverde A: Membrane-active peptides for non-viral gene therapy: making the safest easier. Trends Biotechnol 2008, 26:267-275.

82. Rosano GL, Ceccarelli EA: Rare codon content affects the solubility of recombinant proteins in a codon bias-adjusted Escherichia coli strain. Microb Cell Fact 2009, 8:41.

83. Lee Y, Zhou T, Tartaglia GG, Vendruscolo M, Wilke CO: Translationally optimal codons associate with aggregation-prone sites in proteins. Proteomics 2010, 10:4163-4171.

84. Kamionka M: Engineering of therapeutic proteins production in Escherichia coli. Curr Pharm Biotechnol 2011, 12:268-274.

85. Vera A, Gonzalez-Montalban N, Aris A, Villaverde A: The conformational quality of insoluble recombinant proteins is enhanced at low growth temperatures. Biotechnol Bioeng 2007, 96:1101-1106.

86. Strandberg L, Enfors SO: Factors influencing inclusion body formation in the production of a fused protein in Escherichia coli. Appl Environ Microbiol 1991, 57:1669-1674.

87. de Marco A, Deuerling E, Mogk A, Tomoyasu T, Bukau B: Chaperone-based procedure to increase yields of soluble recombinant proteins produced in E. coli. BMC Biotechnol 2007, 7:32.

88. de Marco A: Protocol for preparing proteins with improved solubility by co-expressing with molecular chaperones in Escherichia coli. Nat Protoc 2007, 2:2632-2639.

89. de Marco A: Protocol for preparing proteins with improved solubility by co-expressing with molecular chaperones in Escherichia coli. Nat Protoc 2007, 2:2632-2639.

90. Makrides SC: Strategies for achieving high-level expression of genes in Escherichia coli. Microbiol Rev 1996, 60:512-538.

91. Gleeson MA, White CE, Meininger DP, Komives EA: Generation of proteasedeficient strains and their use in heterologous protein expression. Methods Mol Biol 1998, 103:81-94.

92. de Marco A: Strategies for successful recombinant expression of disulfide bond-dependent proteins in Escherichia coli. Microb Cell Fact 2009, 8:26.

93. Gibson TJ, Mccarty K, Mcfadyen IJ, Cash E, Dalmonte P, Hinds KD, et al: Application of a high-throughput screening procedure with PEGinduced precipitation to compare relative protein solubility during formulation development with lgG1 monoclonal antibodies. J Pharm Sci 2011, 100:1009-1021.

94. Bondos SE, Bicknell A: Detection and prevention of protein aggregation before, during, and after purification. Anal Biochem 2003, 316:223-231.

95. Golovanov AP, Hautbergue GM, Wilson SA, Lian LY: A simple method for improving protein solubility and long-term stability. J Am Chem Soc 2004, 126:8933-8939.

96. Ducat T, Declerck N, Gostan T, Kochoyan M, Demene H: Rapid determination of protein solubility and stability conditions for NMR studies using incomplete factorial design. J Biomol NMR 2006, 34:137-151.

97. Gosavi RA, Mueser TC, Schall CA: Optimization of buffer solutions for protein crystallization. Acta Crystallogr D Biol Crystallogr 2008, 64:506-514.

98. Rathore N, Rajan RS: Current perspectives on stability of protein drug products during formulation, fill and finish operations. Biotechnol Prog 2008, 24:504-514.

99. Tiwari AK, Gajbhiye V, Sharma R, Jain NK: Carrier mediated protein and peptide stabilization. Drug Deliv 2010, 17:605-616.

100. Rinas U, Tsai LB, Lyons D, Fox GM, Stearns G, Fieschko J, et al: Cysteine to serine substitutions in basic fibroblast growth factor: effect on inclusion body formation and proteolytic susceptibility during in vitro refolding. Biotechnology NY 1992, 10:435-440.

101. Lawson AJ, Walker EA, White SA, Dafforn TR, Stewart PM, Ride JP: Mutations of key hydrophobic surface residues of 11 betahydroxysteroid dehydrogenase type 1 increase solubility and monodispersity in a bacterial expression system. Protein Sci 2009, 18:1552-1563.

102. Li P, Guan H, Li J, Lin Z: Heterologous expression, purification, and characterization of cytochrome P450sca-2 and mutants with improved solubility in Escherichia coli. Protein Expr Purif 2009, 65:196-203.

103. Kong B, Guo GL: Enhanced In Vitro Refolding of Fibroblast Growth Factor 15 with the Assistance of SUMO Fusion Partner. PLoS One 2011, 6:e20307.

104. Jung HJ, Kim SK, Min WK, Lee SS, Park K, Park YC, et al: Polycationic amino acid tags enhance soluble expression of Candida antarctica lipase B in recombinant Escherichia coli. Bioprocess Biosyst Eng 2011.
105. Kato A, Maki K, Ebina T, Kuwajima K, Soda K, Kuroda Y: Mutational analysis of protein solubility enhancement using short peptide tags. Biopolymers 2007, 85:12-18.

106. Guo W, Cao L, Jia Z, Wu G, Li T, Lu F, et al: High level soluble production of functional ribonuclease inhibitor in Escherichia coli by fusing it to soluble partners. Protein Expr Purif 2011, 77:185-192.

107. Davis GD, Elisee C, Newham DM, Harrison RG: New fusion protein systems designed to give soluble expression in Escherichia coli. Biotechnol Bioeng 1999, 65:382-388.

108. De M, Stier G, Blandin S, de MA: The solubility and stability of recombinant proteins are increased by their fusion to NusA. Biochem Biophys Res Commun 2004, 322:766-771.

109. Mudaliar SR, Lindberg FA, Joyce $M$, Beerdsen $P$, Strange $P$, Lin $A$, et al: Insulin aspart (B28 asp-insulin): a fast-acting analog of human insulin: absorption kinetics and action profile compared with regular human insulin in healthy nondiabetic subjects. Diabetes Care 1999, 22:1501-1506.

110. O'Rourke EC, Drummond RJ, Creasey AA: Binding of 125I-labeled recombinant beta interferon (IFN-beta Ser17) to human cells. Mol Cell Biol 1984, 4:2745-2749.

111. Hsu E, Osslund T, Nybo R, Chen BL, Kenney WC, Morris CF, et al: Enhanced stability of recombinant keratinocyte growth factor by mutagenesis. Protein Eng Des Sel 2006, 19:147-153.

112. Blatt LM, Davis JM, Klein SB, Taylor MW: The biologic activity and molecular characterization of a novel synthetic interferon-alpha species, consensus interferon. J Interferon Cytokine Res 1996, 16:489-499.

113. Justesen S, Buus S, Claesson MH, Pedersen AE: Addition of TAT protein transduction domain and GrpE to human p53 provides soluble fusion proteins that can be transduced into dendritic cells and elicit p53specific T-cell responses in HLA-A*0201 transgenic mice. Immunology 2007, 122:326-334

114. Harada H, Hiraoka M, Kizaka-Kondoh S: Antitumor effect of TAT-oxygendependent degradation-caspase-3 fusion protein specifically stabilized and activated in hypoxic tumor cells. Cancer Res 2002, 62:2013-2018.

115. Vocero-Akbani AM, Heyden NV, Lissy NA, Ratner L, Dowdy SF: Killing HIVinfected cells by transduction with an HIV protease-activated caspase-3 protein. Nat Med 1999, 5:29-33.

doi:10.1186/1475-2859-10-60

Cite this article as: Vazquez et al:: Post-production protein stability: trouble beyond the cell factory. Microbial Cell Factories 2011 10:60.

\section{Submit your next manuscript to BioMed Central and take full advantage of:}

- Convenient online submission

- Thorough peer review

- No space constraints or color figure charges

- Immediate publication on acceptance

- Inclusion in PubMed, CAS, Scopus and Google Scholar

- Research which is freely available for redistribution

Submit your manuscript at www.biomedcentral.com/submit
C Biomed Central 